\title{
Comparative analysis of cytokine transcript profiles within mediastinal lymph node compartments of pigs after infection with porcine reproductive and respiratory syndrome genotype 1 strains differing in pathogenicity
}

Obdulio García-Nicolás ${ }^{1 *}$, Rubén S Rosales², Francisco J Pallarés ${ }^{1}$, David Risco ${ }^{3}$, Juan J Quereda ${ }^{4}$, Simon P Graham ${ }^{5}$, Jean-Pierre Frossard ${ }^{5}$, Sophie B Morgan ${ }^{5}$, Falko Steinbach ${ }^{5,7}$, Trevor W Drew ${ }^{5}$, Tony S Strickland ${ }^{6}$ and Francisco J Salguero 6,7

\begin{abstract}
Porcine reproductive and respiratory syndrome virus (PRRSV) induces a weak immune response enabling it to persist in different organs of infected pigs. This has been attributed to the ability of PRRSV to influence the induction of cytokine responses. In this study, we investigated the cytokine transcriptional profiles in different compartments of the mediastinal lymph node of pigs infected with three genotype 1 PRRSV strains of differing pathogenicity: the low virulence prototype Lelystad virus (LV), and UK field strain 215-06 and the highly virulent subtype 3 SU1-Bel isolate from Belarus. We have used a combination of laser capture micro-dissection (LCM) followed by real time quantitative PCR (RT-qPCR) and immunohistochemical (IHC) detection of immune cell markers (CD3, CD79a and MAC387) and RT-qPCR quantification of PRRSV and cytokine transcripts. Compared to mock infected pigs, we found a significant downregulation of TNF- $a$ and IFN- $a$ in follicular and interfollicular areas of the mediastinal lymph node from 3 days post-infection (dpi) in animals infected with all three strains. This was accompanied by a transient B cell depletion and T cell and macrophage infiltration in the follicles together with $\mathrm{T}$ cell depletion in the interfollicular areas. A delayed upregulation of IFN- $\gamma$ and IL-23p19 was observed mainly in the follicles. The PRRSV load was higher in all areas and time-points studied in the animals infected with the SU1-Bel strain. This paper describes the first application of LCM to study the cytokine transcript profiles and virus distribution in different compartments of the lymph node of pigs.
\end{abstract}

\section{Introduction}

Porcine reproductive and respiratory syndrome (PRRS) is characterized by respiratory disease in neonatal and growing pigs and reproductive failure in gilts and sows (increased number of abortions, mummified foetuses, stillbirth and weak-born piglets) [1-3]. PRRS is considered one of the most economically important swine infectious diseases around the world, with estimated losses of up to $\$ 664$ million annually in the USA alone $[4,5]$.

\footnotetext{
* Correspondence: ogn14346@um.es

'Department of Anatomy and Comparative Pathology, Faculty of Veterinary Medicine, Murcia University, "Mare Nostrum Excellence Campus - 3738", 30100 Murcia, Spain

Full list of author information is available at the end of the article
}

PRRS virus (PRRSV) is classified into two genotypes, type 1 (European or PRRSV-1) and type 2 (North American or PRRSV-2) [6]. In addition, a high degree of genetic variation in both genotypes has been found, with PRRSV-1 having been divided into 3 subtypes: panEuropean subtype 1 and East European subtypes 2 and 3 [7], with the possibility of a fourth subtype being suggested [8]. Significant differences in virulence have also been described between PRRSV-1 subtypes, with the East European subtype 3 seemingly comprising the most virulent strains [9-11].

PRRSV shows a marked tropism for cells of the monocyte-macrophage lineage [12]. The main target of PRRSV are alveolar and other tissue macrophages, and 
to a lesser extent, monocytes and dendritic cells [13]. Absent or weak interferon alpha (IFN- $\alpha$ ) secretion [14] and a consequent weak and delayed cell-mediated immune response with low levels of IFN- $\gamma$ has been described following PRRSV infection [15,16]. Pigs infected with PRRSV have also shown a delayed production of neutralizing antibodies [17]. PRRSV replication has been reported in lymphoid organs $[18,19]$ however studies have also shown a lack of homogeneity in proinflammatory cytokine responses [20-22]. This suggests a role for this tissue in the pathogenesis of PRRS but also highlights the need for comparative in vivo studies using PRRSV-1 strains which differ in their virulence. The porcine lymph node (LN) has a dense medulla, where $\mathrm{T}$ cells are predominant and which lacks sinuses and cords. The LN cortex is divided into two differentiated areas the follicles (F) and interfollicular (IF) areas. The $\mathrm{F}$ is a $\mathrm{B}$ cell rich area that also contains follicular dendritic cells (fDC) and $\mathrm{CD}_{4}^{+} \mathrm{T}$ helper cells that collaborate in antigen presentation to $\mathrm{B}$ cells and subsequent antibody production. The IF area is rich in $\mathrm{T}$ cells $[21,22]$. It has been proposed that the immunopathogenesis of porcine circovirus 2 (PCV2) infection is associated with follicular changes in lymph nodes [23], and it is suggested that this could also be the case for PRRSV infection.

Transcriptional expression profiling studies can aid to the understanding of infection biology and the molecular basis of disease [24]. Several studies have analysed the host transcriptional profiles during PRRSV infection in different organs by taking small pieces of tissue [25-28], but none have addressed transcriptional profiling in defined tissue structures. Laser capture microdissection (LCM) is a powerful tool for the acquisition of homogeneous cell populations or specific tissue structures which can be analyzed by a variety of molecular biology techniques and aid disease pathogenesis investigations [29-31].

The main aim of this study was to compare the cytokine transcriptional profiles in different compartments of lymph nodes from pigs infected with three PRRSV-1 strains of defined virulence. This study included the prototype Lelystad virus (LV) and a field strain from the UK (215-06), both categorized as low virulence subtype 1 viruses, and a divergent and highly pathogenic Eastern European subtype 3 strain from Belarus (SU1-Bel). Using LCM followed by quantitative reverse transcriptase PCR (RT-qPCR), viral RNA and cytokine transcripts were measured in the $\mathrm{F}$ and IF areas of mediastinal lymph nodes (Med-LN) collected at selected time-points post-infection. To further contextualize these data, $T$ cells, B cells and macrophages were immunolabelled to characterize these cell populations within the lymph node compartments.

\section{Material and methods}

\section{Viruses}

Three PRRSV-1 strains were used in this study: the LV-Ter Huurne was selected as the prototype subtype 1 strain (kindly provide by Anne Marie Rebel, CVI Lelystad, The Netherlands) [11]; the subtype 1 215-06 strain was isolated in 2006 from the serum of a post-weaning piglet showing signs of wasting and poor condition on a farm in England and isolated at the Animal and Plant Health Agency (APHA, Addlestone, UK); and the highly pathogenic subtype 3 strain SU1-Bel, isolated at the APHA from lung tissue of a pig from Belarus (kindly provided by Dr Tomasz Stadejek, Warsaw University of Life Sciences, Poland) was also included. Virus propagation was carried out as previously described [10].

\section{Animals and experiment design}

Seventy-six specific-pathogen-free five-week-old male piglets from a PRRSV and PCV2 seronegative farm in the Netherlands were used in this study. These animals were matched by weight and randomly allocated to four groups; for the control group 16 animals were allocated, whereas for each infected group 20 animals were used. Each group was housed in separate rooms, which allowed the free airflow from the outside, and were allowed to acclimatise for 14 days prior to the experiment. Measures were taken to prevent cross-contamination between groups, including the change of clothes and equipment between each room. At seven weeks of age, 3 groups of piglets were inoculated intranasally with $1.5 \mathrm{~mL}$ of complete Roswell Park Memorial Institute medium supplemented with 10\% FBS (cRPMI) containing $10^{5} 50 \%$ tissue-culture infective dose $\left(\mathrm{TCID}_{50}\right)$ of PRRSV-1 strain (LV, 215-06 and SU1-Bel, respectively). The remaining control group was inoculated intranasally with $1.5 \mathrm{~mL}$ of uninfected porcine alveolar macrophage cryolysate in cRPMI. Four animals in the control group and five from each virus-inoculated group were euthanized at 3 and at 7 days post-infection (dpi). All remaining animals were euthanized at $35 \mathrm{dpi}$. This experiment was performed in accordance with the Animals (Scientific Procedures) Act, 1986, UK, following approval of the APHA Ethical Review Committee. A clinical scoring system with predefined humane endpoints was used to prevent undue suffering.

\section{Clinical signs, gross pathology and histopathology}

Pigs were monitored daily throughout the study, and clinical signs, including rectal temperatures, were scored and recorded as previously described [10]. The Med-LN is the main draining lymph node for the apical and medial lobes of the lungs. Since PRRSV is most frequently detected in these lung lobes [32], Med-LN was selected for this study and the gross pathology evaluated during post-mortem examination. For the analysis by RT-qPCR, a 
piece of $10 \times 10 \times 3 \mathrm{~mm}$ of Med-LN was embedded and cryopreserved in optimal cutting temperature (OCT) compound (Sakura Finetek Europe B.V., The Nederland) as previously described [33]. For histopathology examination, the remaining Med-LN samples were fixed in 10\% buffered formalin, routinely processed, embedded in paraffin-wax, and $4 \mu \mathrm{m}$ tissue sections stained with haematoxylin and eosin. The histopathological lesions were evaluated in these slides using a light microscope.

\section{Immunohistochemistry (IHC)}

The immunolabelling of cell markers was done using the avidin-biotin complex method (ABC Vector Elite, Vector laboratories, USA) as described previously [19,34]. Briefly, $4 \mu \mathrm{m}$ thick sections were dewaxed and rehydrated, followed by endogenous peroxidase inhibition with $3 \%$ $\mathrm{H}_{2} \mathrm{O}_{2}$ in methanol for $30 \mathrm{~min}$. Depending on the epitope of interest, antigen retrieval in the tissue sections was performed by enzymatic trypsin/alpha-chymotrypsin (for CD3 and MAC-387) or by microwaving the sections in citric acid pH6.0 (for CD79a) or pH6.0 citrate buffer (for PRRSV nucleocapsid N protein). The slides were mounted in a Sequenza Immunostaining Centre (Shandon Scientific, UK) and washed with Tris buffered saline (TBS; $\mathrm{pH}$ 7.6, $0.005 \mathrm{M}$; Sigma-Aldrich, UK) and incubated for $30 \mathrm{~min}$ at room temperature with $100 \mu \mathrm{L}$ per slide of blocking solution. The primary antibodies used were monoclonal anti-human CD3 (1:1000; Dako, UK), monoclonal antihuman CD79a (1:400; Dako, UK), and monoclonal anti-human MAC-387 (1:100; AbDSerotec, UK). Each antibody was applied for $1 \mathrm{~h}$ at room temperature. In each case, the corresponding biotinylated secondary antibody (Vector Laboratories, UK) was then incubated for $30 \mathrm{~min}$ at room temperature. Slides were then incubated for $30 \mathrm{~min}$ with avidin-biotin complex and labelling performed using 3,30-diaminobenzidine tetrahydrochloride (DAB; Sigma-Aldrich, UK). Sections were counterstained with Mayer's haematoxylin, dehydrated and mounted. Positive and negative controls, as well as isotype controls, were included in each IHC run.

The immunolabelled Med-LN sections were examined by light microscopy, and immunolabelling measurements recorded using a score ranking from -3 to 0 (cellular depletion) and from 0 to 3 (cellular increment) compared to the control group. Positive scale: $0=$ absence $(<1$ positive cell/structure); $1=$ scarce $(1-10$ positive cells/structure); 2 mild-moderate (11-30 positive cells/ structure); 3 abundant ( $>31$ positive cells/structure). Negative scale: $0=$ absence (no different to control group); $-1=$ scarce $(5 \%$ less positive cells compares with control group); -2 mild-moderate (6-10\% less positive cells compares with control group); -3 abundant (more than 10\% less positive cells compares with control group).

\section{Laser capture microdissection (LCM)}

Frozen OCT-embedded Med-LNswere cut to $10 \mu \mathrm{m}$ thick sections using a cryostat. Tissue sections were placed on membrane-coated slides (PEN-Membrane $2.0 \mu \mathrm{m}$; Leica Microsystems, Germany). The cryostat was treated with RNAZap Solution (Life Technologies, UK) between each sample in order to avoid cross-contamination of RNA. Sections were air-dried and fixed in 70\% ethanol for $5 \mathrm{~min}$ and stained with RNase free haematoxylin for $1 \mathrm{~min}$. Two consecutive Med-LN tissue sections were used per animal. All observed $F$ and peripheral IF were dissected and captured separately in RNase-free PCR tubes (Greiner bio-one, UK) using a laser microdissector (Leica LMD6500, Leica, Germany). The samples were immediately frozen and stored at $-80^{\circ} \mathrm{C}$ until laboratory processing.

\section{RNA extraction and reverse transcription quantitative polymerase chain reaction (RT-qPCR)}

For each sample, total RNA was extracted using the RNA queous-Micro Kit (Ambion,Life Technologies, UK) following the manufacturer's instructions for LCM samples, including the DNase I treatment and DNase inactivation steps. The total RNA was quantified using Qubit 2.0 Fluorometer (Life Technologies) and all samples adjusted to an RNA concentration of $2 \mathrm{ng} / \mu \mathrm{L}$ ).

PRRSV infection kinetics in the $\mathrm{F}$ and IF areas of Med-LN were studied by measuring viral RNA. PRRSV RT-qPCR was performed as previously described [35]. Briefly, $2 \mu \mathrm{L}$ of sample or standard PRRSV-1 RNA dilutions were added as template to the QuantiTec Probe RT-PCR Kit (Qiagen, UK) following the manufacturer's instructions for a total volume of $25 \mu \mathrm{L}$. Data was analysed by changes in the cycle threshold $(\mathrm{Ct})$, and results were calculated as $38-\mathrm{Ct}$, which represented the difference between the last cycle of the PRRSV RT-qPCR and the Ct for each sample.

Primers and TaqMan probe sets for porcine cytokines were synthesized by Sigma-Aldrich (Table 1 ). All cytokines primer pairs produced amplicons smaller than 150 base pairs (bp). All primer and probe sets were optimized for our laboratory conditions.

In order to obtain complementary DNA (cDNA) reverse transcription was carried out using the SuperScript VILO $^{\mathrm{TM}}$ cDNA Synthesis Kit (Applied Biosystems, UK) and cDNA was stored at $-80{ }^{\circ} \mathrm{C}$ until laboratory processing. $2 \mu \mathrm{L}$ of cDNA diluted 1:100 in RNase free water was used as template for each cytokine qPCR, using the EXPRESS qPCR Supermix (Invitrogen) with ROX reference dye in a total volume of $20 \mu \mathrm{L}$. Thermal cycling conditions were 2 min at $95{ }^{\circ} \mathrm{C}, 45$ cycles of denaturation at $95^{\circ} \mathrm{C}$ for $15 \mathrm{~s}$ and annealing/extension at $60{ }^{\circ} \mathrm{C}$ for $1 \mathrm{~min}$. Reverse transcription negative controls and non-template controls were included. PCR plates were centrifuged prior to 
Table 1 Primers and probes used for qPCR

\begin{tabular}{|c|c|c|c|}
\hline Gene & $\begin{array}{l}\text { Primer Forward } \\
\mathrm{nM}\end{array}$ & $\begin{array}{c}\text { Primer Reverse } \\
\mathrm{nM}\end{array}$ & $\begin{array}{c}\text { Probe } \\
\mathrm{nM}\end{array}$ \\
\hline \multirow[t]{2}{*}{$\beta$-Actin } & $5^{\prime}$-cactcctaacgctgtggatcag-3' & $5^{\prime}$-ccacttaactatcttgggcttatcg-3' & 5'-[6FAM]-cacgtgcttcacgcggcagc-[TAM]-3' \\
\hline & 300 & 300 & 50 \\
\hline \multirow[t]{2}{*}{ TNF- $a$} & $5^{\prime}$-tggecccttgagcatca-3' & $5^{\prime}$-cgggcttatctgaggtttgaga-3' & $5^{\prime}-[6 F A M]-c c c t c t g g c c c a a g g a c t c a g a t c a-[T A M]-3^{\prime}$ \\
\hline & 900 & 600 & 50 \\
\hline \multirow[t]{2}{*}{ IFN-a } & $5^{\prime}$-tcagctgcaatgccatctg-3' & $5^{\prime}$-agggagagattctcctcatttgtg-3' & $5^{\prime}$-[6FAM]-tgacctgcctcagacccacagcc-[TAM]-3' \\
\hline & 150 & 600 & 50 \\
\hline \multirow[t]{2}{*}{ IFN- $\gamma$} & $5^{\prime}$-gaaaagctgattaaattccggtag-3' & 5'-aggttagatcttggtgacagatc-3' & $5^{\prime}$-[6FAM]-tctgcagatccagcgcaaagccatcag-[TAM]-3' \\
\hline & 300 & 900 & 50 \\
\hline \multirow[t]{2}{*}{ SOCS1 } & $5^{\prime}$-ttcttcgecctcagtgtgaa-3' & $5^{\prime}$-ggcctggaagtgcacgc-3' & $5^{\prime}$-[6FAM]-ttcgggecccacaagcatcc-[TAM]-3' \\
\hline & 300 & 300 & 50 \\
\hline \multirow[t]{2}{*}{ IL-10 } & $5^{\prime}$-tgagaacagctgcatccacttc-3' & $5^{\prime}$-tctggtccttcgtttgaaagaaa-3' & $5^{\prime}$-[6FAM]-caaccagcctgccccacatgc-[TAM]-3' \\
\hline & 300 & 300 & 150 \\
\hline \multirow[t]{2}{*}{ TGF- $\beta$} & 5'-agggctaccatgccaattt-3' & $5^{\prime}$-ccgggttgtgctggttgt-3' & $5^{\prime}$-[6FAM]-cactcagtacag caaggtcctggctctgta-[TAM]-3 \\
\hline & 600 & 600 & 50 \\
\hline \multirow[t]{2}{*}{ IL-23p19 } & 5'-agaagagggagatgatgagac-3' & $5^{\prime}$-agcaggactgactgccgtcc-3' & 5'-[6FAM]-ctgaggatcacagccatccccgc-[TAM]-3' \\
\hline & 900 & 300 & 50 \\
\hline
\end{tabular}

amplification using the Strategene MX3000P qPCR System (Stratagene, UK). Fold-change of cytokine expression was calculated using the $2^{-\Delta \Delta C t}$ method [36] and $\beta$-actin was used as the endogenous calibrator; which was selected due to its stable expression in porcine lymphatic tissue [37]. Relative gene expression results are presented on a base 2 logarithmic scale.

\section{Statistical analysis}

Statistical analyses were performed using SPSS 15.0 software (SPSS Inc., USA) and graphs were prepared using SPSS 15.0 software (SPSS Inc., USA) and GraphPad Prism 5 (GraphPad Software, Inc., USA). To determine the non-normal distribution of all data a KolmogorovSmirnov test was used. Non-normal distributed data was then analysed using a non-parametric test. The Kruskal-Wallis test was performed to analyse the mean parameters (PRRSV RNA load, immunolabelled cells and cytokine expression) between the animal groups (Control, LV, 2015-06, and SU1-Bel) at three different time-points post inoculation ( $3 \mathrm{dpi}, 7 \mathrm{dpi}$, and $35 \mathrm{dpi}$ ). Thereafter, we performed multiple comparisons using the nonparametric Mann-Whitney-U test with Bonferroni correction as post-hoc to determine significant individual differences. Finally, the presence of differences between results obtained in $F$ and IF tissues were assessed using the non-parametric Wilcoxon signedrank test. The correlations between PRRSV RNA and cytokine transcripts were determined by Spearman's Rho analysis. A $p$ value of less than 0.05 was considered significant.

\section{Results}

\section{Clinical signs, gross pathology and histopathology}

Rectal temperatures remained within the physiological range in control as well as infected animals, except for SU1-Bel infected animals that showed hyperthermia at 3, 8-10 dpi (over $40{ }^{\circ} \mathrm{C}$ ). Only SU1-Bel infected animals developed elevated clinical sign scores (mean score from 5 to 10$)$ compared with the rest of animals in this study (mean clinical score only up to 3) [10]. Macroscopically at post-mortem, a mild to moderate enlargement of Med-LN was observed in infected animals at 3 and 7 dpi, while at 35 dpi no Med-LN damage was observed [10]. The control animals did not show any lesions during the study. The histopathological analysis of Med-LN revealed the presence in the lymphoid follicles of a mild hypertrophy of germinal centres and the presence of apoptotic bodies at 3 and $7 \mathrm{dpi}$. At $35 \mathrm{dpi}$ virus-infected groups showed no significant histological lesions.

\section{PRRSV RNA quantification}

All PRRSV RNA measurements are shown in Figure 1. All PRRSV infected animals showed a higher PRRSV RNA load at 3 and $7 \mathrm{dpi}$ than at $35 \mathrm{dpi}(p<0.05)$. No viral RNA was detected in control animals (data not shown). The LV group showed at $3 \mathrm{dpi}$ higher viral RNA in the IF area of Med-LN $(38-\mathrm{Ct}=18.89 \pm 1.27 \mathrm{SD}$; $p<0.05)$. At $7 \mathrm{dpi}$ the viral RNA amount was similar between Med-LN compartments $(38-\mathrm{Ct}=18.89 \pm 1.90 \mathrm{SD}$; $38-\mathrm{Ct}=19.09 \pm 0.58 \mathrm{SD} ; \mathrm{F}$ and IF areas respectively). At 35 dpi the LV RNA was significantly reduced in Med-LN 


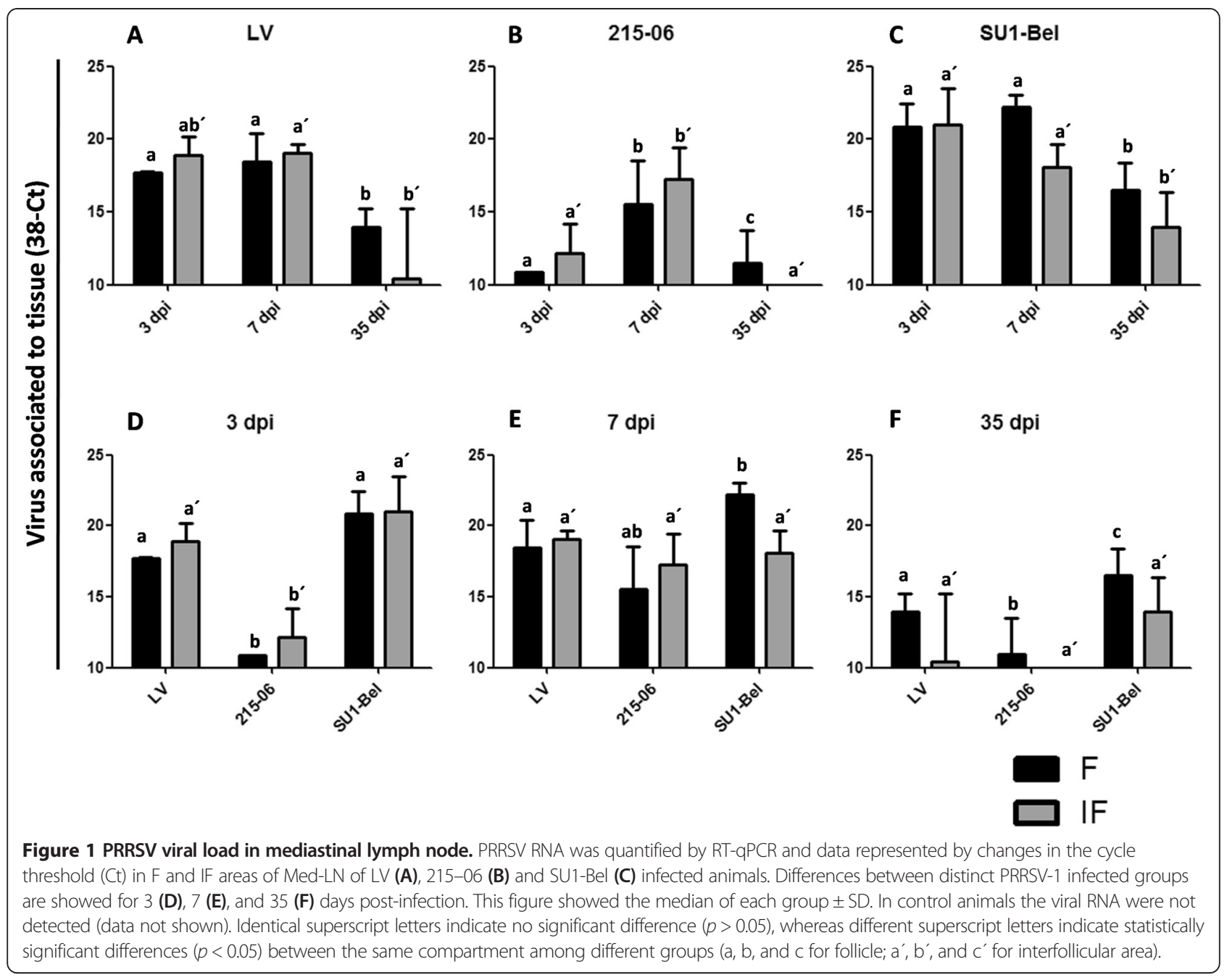

compartments $(38-\mathrm{Ct}=13.98 \pm 1.23 ; 38-\mathrm{Ct}=10.46 \pm$ 4.76; F and IF area respectively; $p<0.05$ ) (Figure 1A).

The PRRSV-1 215-06 RNA was detected at $3 \mathrm{dpi}$ mainly in IF area of Med-LN (38 - Ct $=12.16 \pm 2.02$; $p<0.05)$. At 7 dpi the 215-06 RNA increased to the highest level seen in the study in this group, and was higher in IF area than in $\mathrm{F}(38-\mathrm{Ct}=17.27 \pm 2.16 ; 38-\mathrm{Ct}=15.55 \pm$ 2.96 ; respectively; $p<0.05)$. Interestingly the $215-06$ virus was only detected in F of Med-LN at 35 dpi (38 $\mathrm{Ct}=10.94 \pm 2.55 ; p<0.05$ ) (Figure $1 \mathrm{~B})$.

At 3 dpi PRRSV-1 SU1-Bel RNA was mostly detected in IF $(38-\mathrm{Ct}=21.03 \pm 2.43 ; p<0.05)$, whereas at $7 \mathrm{dpi}$ SU1-Bel RNA was mostly found in F $(38-\mathrm{Ct}=22.20 \pm$ $0.85 ; p<0.05)$. At 35 dpi the SU1-Bel RNA decreased but was statistically significant in both Med-LN compartments although predominantly detected in $\mathrm{F}$ of Med-LN $(38-\mathrm{Ct}=16.49 \pm 1.88 ; p<0.05)$ (Figure 1C).

The SU1-Bel group showed the higher load of viral RNA in both Med-LN compartments at each time-point throughout this study (Figures 1D-F; $p<0.05$ ). At $3 \mathrm{dpi}$, PRRSV RNA was mainly detected in IF areas (Figure 1D), where the 215-06 RNA amount was statistically significant lower than in LV and SU1-Bel groups $(p<0.05)$. PRRSV RNA remained higher in IF compartment at 7 dpi for LV and 215-06 groups, but it was higher in F of SU1-Bel-infected pigs $(p<0.05$; Figure 1E). By $35 \mathrm{dpi}$, the SU1-Bel RNA in F was statistically significant higher than in LV infected group $(p<0.05)$, and in both groups it was significant higher than in F of Med-LN of 215-06 infected animals $(p<0.05$; Figure $1 \mathrm{~F})$.

\section{Immunohistochemistry (IHC)}

CD3 immunolabelling defined the $\mathrm{T}$ cell population locations in Med-LN [38,39]. During this study the number of $\mathrm{T}$ cells was found to be increased in F of Med-LN at $7 \mathrm{dpi}$ in all infected animals compared with the control animals (2 semi-quantitative immunolabelled cells [s-qic] for LV and 215-06 groups and 3 s-qic for the SU1-Bel group; $p<0.05)$. At $35 \mathrm{dpi}$ this follicular $\mathrm{T}$ cell population remained statistically higher in LV infected animals (2 s-qic for LV; $p<0.05$; Figure 2A). Conversely, the number of $\mathrm{T}$ cells decreased in the Med-LN IF from 


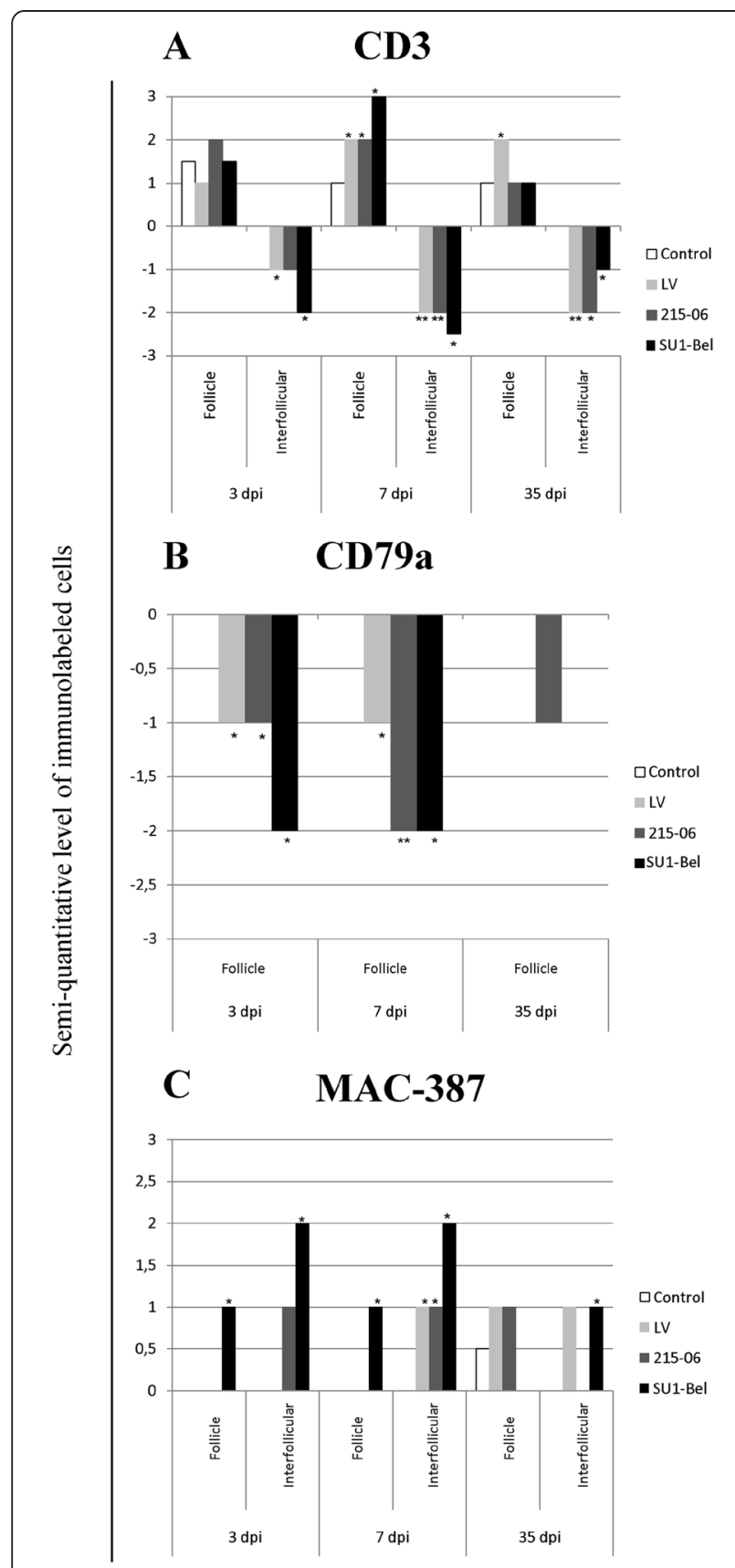

Figure 2 Immunolabelled cell populations in mediastinal lymph node of PRRSV-1 infected pigs. A. CD3 staining for T cells detection; it was observed a general T cell depletion during this study for all PRRSV infected groups, otherwise the T cell immunolabeled cells increased in F at 7 dpi. B. CD79a staining for B cell staining in follicle, where was evidence a B cell depletion at 3 and 7 dpi for all PRRSV infected animals. C. Macrophage detection with MAC-387 staining, the amount of immunolabeled macrophages increased along this study in SU1-Bel infected pigs. The bars represent s-qic mean values; asterisks indicated the statistically significant differences $(p<0.05)$ against the control group. It is important to note that only a few animals in the control groups showed a higher number of immunolabeled cells in the follicle compared to the rest of animals within this group. For this reason there is a bar in some control groups.
3 dpi in LV $(-1$ s-qic; $p<0.05)$ and SU1-Bel inoculated animals $(-2$ s-qic; $p<0.05)$, remaining lower than control animals at 7 and $35 \mathrm{dpi}$ for all infected animals ( $-2 \mathrm{~s}$-qic for LV and 215-06, and from -2.5 to $-1 \mathrm{~s}$-qic for SU1-Bel; $p<0.05$; Figure 2A).

The immunolabelling of the pan- $\mathrm{B}$ cell surface protein CD79a $[40,41]$ showed B cells only in the F of Med-LN. In all infected animals these cells decreased in number compared with control animals at 3 dpi $(-1 \mathrm{~s}$-qic for LV and 215-06 and -2 s-qic for SU1-Bel groups; $p<0.05)$ and 7 dpi (-1 s-qic for LVand -2 s-qic for both 215-06 and SU1-Bel groups; $p<0.05)$. At 35 dpi the B cell population did not show a statistically significant change between the infected and control groups (Figure 2B).

Macrophages were identified through MAC-387 imunolabelling of Med-LN sections [21,42]. In the F, macrophage numbers were found to be statistically increased in SU1-Bel infected animals at 3 and $7 \mathrm{dpi}$ (1 s-qic on both days; $p<0.05$ ). In the IF areas of SU1-Bel infected animals, the macrophage population was increased at all time-points (from 2 to 1 s-qic; $p<0.05$ ). However the animals inoculated with LV and 215-06 PRRSV strains showed a smaller increase in macrophages in the IF area only at $7 \mathrm{dpi}$ ( $1 \mathrm{~s}$-qic; $p<0.05$; Figure $2 \mathrm{C}$ ).

Representative images of CD3, CD79a and MAC387 IHC staining in all the groups are shown in Figure 3.

\section{Cytokine gene expression in Med-LN compartments}

To assess immune responses against the selected PRRSV-1 strains within the different Med-LN compartments, IFN- $\alpha$, TNF- $\alpha$, IFN- $\gamma$, IL-23p19, SOCS1, IL-10 and TGF- $\beta$ transcript levels were measured by RT-qPCR and compared against control animals (Figure 4). The suitability of the RNA quality was confirmed by testing expression of $\beta$-actin in the samples. All cDNA samples produced a positive amplification to each gene by qPCR.

Compared to control animals, in both studied LN compartments the IFN- $\alpha$ was generally downregulated in all infected groups and time-points, which was statistically significant for all PRRSV-1 strains at $7 \mathrm{dpi}(p<0.05)$, when the SU1-Bel group showed the lowest IFN- $\alpha$ transcript levels. The IFN- $\alpha$ remained downregulated at $35 \mathrm{dpi}$ in the Med-LN of 215-06 and Su1-Bel infected pigs $(p<0.05$; Figure 4A). TNF- $\alpha$ expression was downregulated in IF area of Med-LN of LV infected pigs at 3 dpi $(p<0.05)$ and in Med-LN of 215-06 group at 35 dpi $(p<0.05$; Figure 4B) compared with the control groups. IFN $-\gamma$ was significantly upregulated in F of Med-LN of LV $(p<0.05)$ and SU1-Bel infected pigs at 7dpi $(p<0.05)$; on the other hand the IFN- $\gamma$ was significant downregulated in IF area of Med-LN of 215-06 infected animals at 35 dpi $(p<0.05$; Figure 4C). At $35 \mathrm{dpi}$, IL-23p19 was statistically significant upregulated in $\mathrm{F}$ of all infected groups ( $p<0.05$; Figure 4D). 


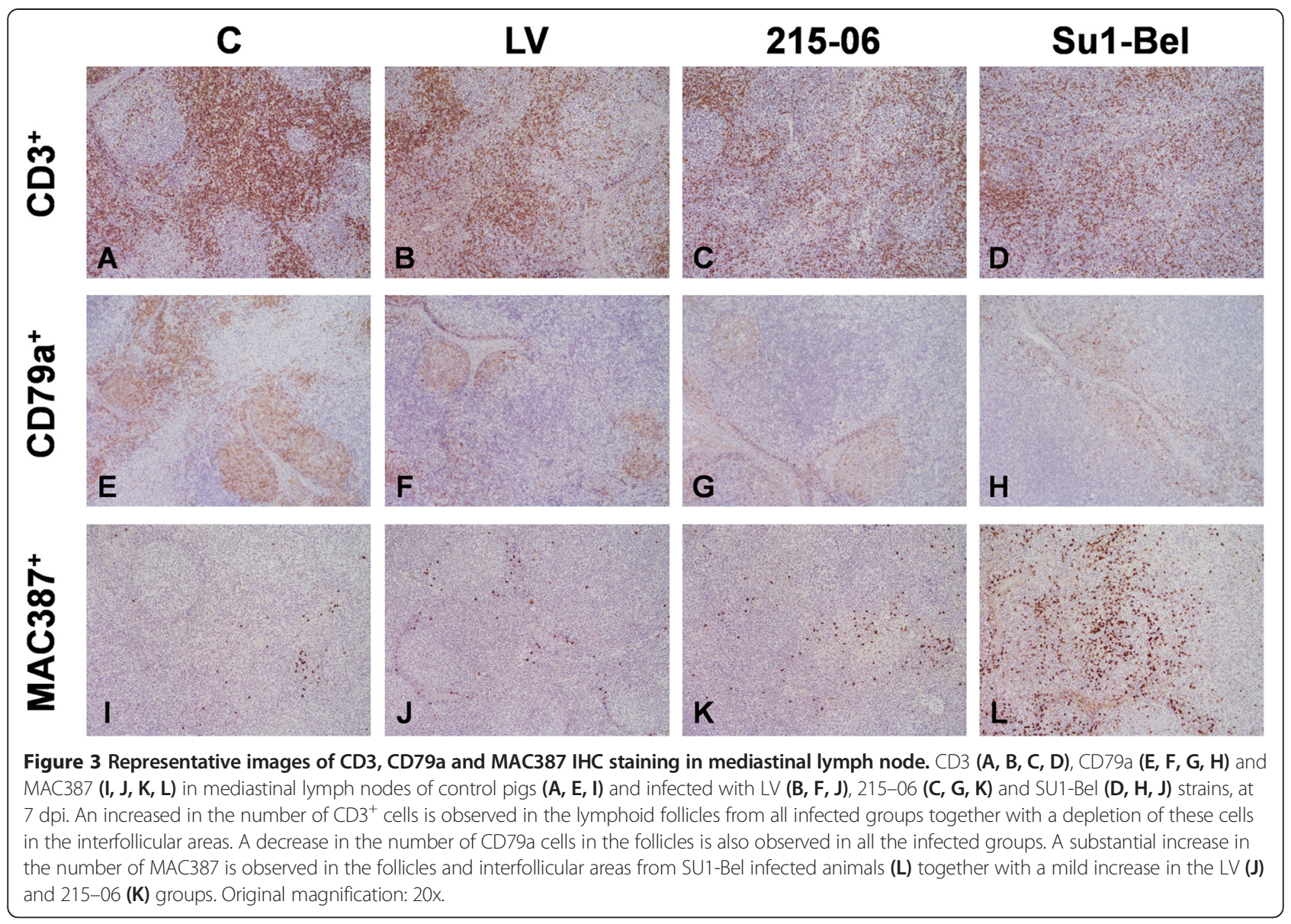

No significant differences in the expression IL-12 mRNA were detected during the study (data not shown). SOCS1 transcript levels were not statistically significantly regulated for any infected group during the first week of this experiment. However at $35 \mathrm{dpi}$, SOCS1 transcript levels were increased in the IF area of the Med-LN of animals from the 215-06 group ( $p<0.05$; Figure 4E). At 7 dpi the IL-10 gene expression was significantly downregulated in the F of both 215-06 and SU1-Bel groups $(p<0.05)$ and in the IF area $(p<0.05$; only 215-06 group). In contrast, IL-10 was significantly upregulated in IF area of Med-LN of the LV infected group $(P<0.05$; Figure $4 \mathrm{~F})$. TGF- $\beta$ was statistically significantly downregulated at $3 \mathrm{dpi}$ in IF areas of Med-LN of 215-06 and SU1-Bel infected animals $(p<0.05)$, at $7 \mathrm{dpi}$ in Med-LN of SU1-Bel group $(p<0.05)$, and at $35 \mathrm{dpi}$ in IF area of Med-LN of $215-06$ infected pigs $(p<0.05)$; contrary, it was statistically upregulated in $\mathrm{F}$ of the $\mathrm{LV}$ group at $35 \mathrm{dpi}(p<0.05$; Figure $4 \mathrm{G})$.

The statistically significant correlations between gene expression of immune genes in Med-LN compartments and LV, 215-06 and SU1-Bel PRRSV RNA are respectively represented in the Tables 2, 3 and 4.

\section{Discussion}

This study reveals additional data generated from an animal experiment conducted at APHA as part of the EU FP7 PoRRSCon project $[10,43]$. This study was conceived to directly compare the modulation of immune response transcripts from defined Med-LN compartments of pigs experimentally infected with PRRSV-1 strains of varying virulence.

Pigs infected with the SU1-Bel PRRSV strain have shown greater Med-LN gross pathology compared with the pan-European subtype 1 strains LV and 215-06 [10]. In the present study the highest PRRSV RNA levels were detected in the IF area of Med-LN, which suggest that PRRSV was entering from the apical and medial lung lobes [32] to the Med-LN via draining lymphatics vessels. We have previously shown that for all PRRSV infected groups, the virus load in serum showed a peak at 7 dpi decreasing until $28 \mathrm{dpi}$, whereas in bronchoalveolar lavage fluid (BALF) the virus persisted until 35 dpi [10]. Interestingly, despite its enhanced virulence the levels of virus in both circulation and BALF were lowest in SU1-Bel infected animals. In contrast, in the present analysis we have detected the higher levels for SU1-Bel in 


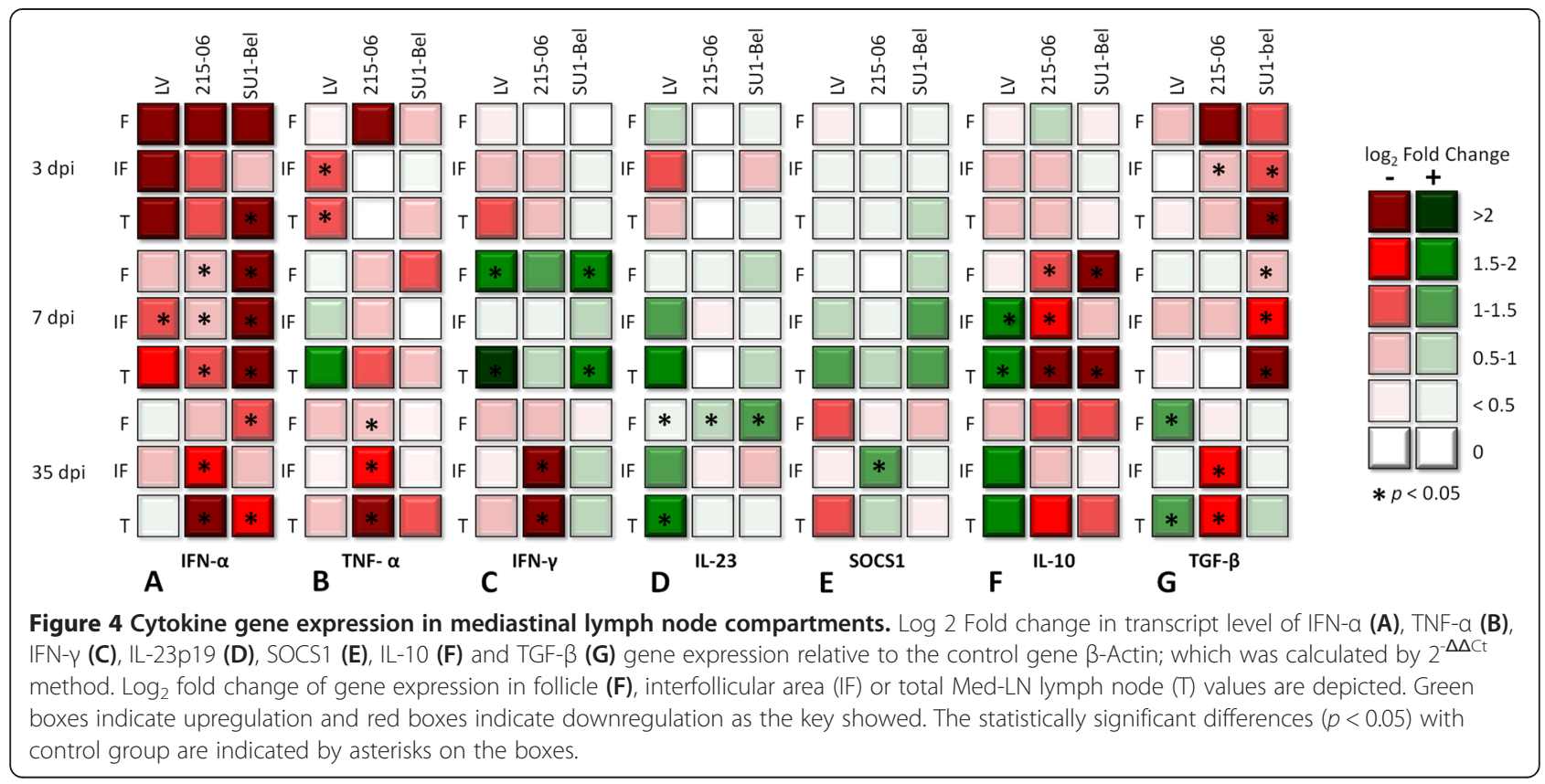

Table 2 Correlations between LV RNA and the gene expression of TNF- $\alpha$, IFN- $\alpha$, IFN- $\gamma$, SOCS1, IL-23p19, IL-10 and TGF- $\beta$

\begin{tabular}{|c|c|c|c|c|c|c|c|c|}
\hline & & IFN-a & IFN- $\nu$ & IL-23 & SOCS1 & IL-10 & TGF- $\beta$ & ORF7 PRRSV \\
\hline \multirow[t]{3}{*}{ TNF- $a$} & $\mathrm{~F}$ & $0.857^{* *}$ & 0.094 & -0.102 & 0.064 & 0.160 & $0.964^{* *}$ & -0.077 \\
\hline & IF & 0.184 & 0.469 & $0.643^{*}$ & 0.471 & $0.687^{* *}$ & 0.479 & -0.190 \\
\hline & $\mathrm{T}$ & $0.750^{* *}$ & 0.248 & 0.031 & 0.091 & 0.305 & $0.921^{* *}$ & -0.043 \\
\hline \multirow[t]{3}{*}{ IFN-a } & $F$ & & -0.255 & -0.351 & 0.009 & -0.201 & $0.901^{* *}$ & -0.110 \\
\hline & IF & & 0.307 & 0.276 & -0.086 & 0.094 & $0.619^{*}$ & $-0.663^{* *}$ \\
\hline & $T$ & & -0.142 & -0.156 & -0.132 & 0.167 & $0.880^{* *}$ & -0.301 \\
\hline \multirow[t]{3}{*}{ IFN- $\nu$} & $\mathrm{F}$ & & & 0.342 & $0.607^{*}$ & 0.131 & -0.082 & 0.413 \\
\hline & IF & & & 0.220 & $0.680^{* *}$ & 0.100 & 0.282 & 0.144 \\
\hline & $\mathrm{T}$ & & & 0.167 & $0.649^{* *}$ & 0.222 & 0.008 & 0.438 \\
\hline \multirow[t]{3}{*}{ IL-23 } & $F$ & & & & 0.239 & 0.112 & -0.179 & -0.208 \\
\hline & IF & & & & 0.109 & $0.553^{*}$ & 0.183 & -0.231 \\
\hline & $\mathrm{T}$ & & & & -0.004 & 0.395 & -0.106 & -0.154 \\
\hline \multirow[t]{3}{*}{ SOCS1 } & $F$ & & & & & 0.809 & -0.063 & $0.527^{*}$ \\
\hline & IF & & & & & 0.310 & -0.016 & 0.303 \\
\hline & $T$ & & & & & 0.211 & -0.139 & 0.486 \\
\hline \multirow[t]{3}{*}{ IL-10 } & $F$ & & & & & & -0308 & 0.397 \\
\hline & IF & & & & & & 0.116 & -0.332 \\
\hline & $T$ & & & & & & 0.144 & -0.151 \\
\hline \multirow[t]{3}{*}{ TGF- $\beta$} & $F$ & & & & & & & -0.206 \\
\hline & IF & & & & & & & $-0.557^{*}$ \\
\hline & $T$ & & & & & & & -0.245 \\
\hline
\end{tabular}

${ }^{*} p<0.05 ;{ }^{* *} p<0.01 . \mathrm{F}$ (follicle of Med-LN), IF (interfollicular area of Med-LN) and T (Total cortical compartments of Med-LN). 
Table 3 Correlations between 215-06 RNA and the gene expression of TNF- $a$, IFN- $a$, IFN- $\gamma$, SOCS1, IL-23p19, IL-10 and TGF- $\beta$

\begin{tabular}{|c|c|c|c|c|c|c|c|c|}
\hline & & IFN- $a$ & IFN- $\gamma$ & IL-23 & SOCS1 & IL-10 & TGF- $\beta$ & ORF7 PRRSV \\
\hline \multirow[t]{3}{*}{ TNF- $a$} & $F$ & 0.66 & -0.015 & $0.679^{*}$ & 0.462 & -0.169 & $0.919^{* *}$ & 0.099 \\
\hline & IF & -0.149 & $0.490^{*}$ & 0.239 & 0.081 & 0.204 & 0.438 & 0.133 \\
\hline & $\mathrm{T}$ & -0.010 & 0.349 & 0.380 & 0.123 & 0.254 & 0.386 & -0.024 \\
\hline \multirow[t]{3}{*}{ IFN- $a$} & $\mathrm{~F}$ & & -0.316 & -0.482 & -0.445 & $-0.666^{*}$ & 0.073 & 0.129 \\
\hline & IF & & 0.145 & 0.091 & -0.399 & -0.137 & 0.188 & 0.252 \\
\hline & $\mathrm{T}$ & & -0.077 & 0.070 & -0371 & $-0.476^{*}$ & 0.378 & 0.205 \\
\hline \multirow[t]{3}{*}{ IFN- $\gamma$} & $F$ & & & 0.016 & 0.193 & 0.257 & 0.067 & $0.612^{*}$ \\
\hline & IF & & & 0.002 & -0.385 & -0.123 & $0.808^{* *}$ & $0.661^{* *}$ \\
\hline & $\mathrm{T}$ & & & -0.068 & 0.133 & 0.178 & 0.436 & $0.524^{*}$ \\
\hline \multirow[t]{3}{*}{ IL-23 } & $F$ & & & & 0.233 & 0.266 & 0.526 & -0.208 \\
\hline & IF & & & & 0.135 & 0.324 & -0.225 & 0.017 \\
\hline & $\mathrm{T}$ & & & & 0.395 & 0.403 & 0.070 & -0.022 \\
\hline \multirow[t]{3}{*}{ SOCS1 } & $\mathrm{F}$ & & & & & 0.362 & 0.420 & -0.013 \\
\hline & IF & & & & & 0.374 & -0.267 & -0.221 \\
\hline & $\mathrm{T}$ & & & & & $0.560^{*}$ & 0.206 & -0.201 \\
\hline \multirow[t]{3}{*}{ IL-10 } & $\mathrm{F}$ & & & & & & -0.173 & -0.114 \\
\hline & IF & & & & & & -0.261 & -0.334 \\
\hline & $\mathrm{T}$ & & & & & & 0.124 & -0.341 \\
\hline \multirow[t]{3}{*}{ TGF- $\beta$} & $F$ & & & & & & & 0.235 \\
\hline & IF & & & & & & & $0.582^{*}$ \\
\hline & $\mathrm{T}$ & & & & & & & 0.276 \\
\hline
\end{tabular}

${ }^{*} p<0.05 ;{ }^{* *} p<0.01 . \mathrm{F}$ (follicle of Med-LN), IF (interfollicular area of Med-LN) and T (Total cortical compartments of Med-LN).

Med-LN compared with the subtype 1 strains, which suggest that this PRRSV-1 subtype 3 strainmay infect LN resident/transient cell populations more efficiently and this could be linked to the higher pathogenicity of this strain. In support of this data, the PRRSV $\mathrm{N}$ protein has been detected by IHC mainly in the cytoplasm of macrophages of the Med-LN of infected pigs from on 3, 7 and $35 \mathrm{dpi}$, with highest levels of immunolabelled cells found in SU1-Bel infected animals [43].

The use of LMD in the present study, enabled for the first time the measurement of PRRSV-1 RNA within different Med-LN compartments. The results showed the presence of PRRSV in the F of the Med-LN at $35 \mathrm{dpi}$ albeit at low levels, according with a previous report that described the detection of infectious PRRSV in lymphoid tissues for several months [39]. We hypothesize that PRRSV may interact with $\mathrm{fDC}$ in secondary lymph organs, such as the Med-LN, and this could impair fDC presentation of PRRSV antigens to B cells, which could contribute to the lack of production of neutralizing antibodies detected in this [10] and other PRRSV infection studies. PRRSV presence in follicles of Med-LN and the non-neutralizing $\mathrm{Ab}$ secretion at $35 \mathrm{dpi}$ suggest a role of $\mathrm{fDC}$ in the immunopathogenesis of PRRSV.
The $\mathrm{B}$ and $\mathrm{T}$ cell depletion observed in $\mathrm{F}$ and IF areas of Med-LN during this study are in accordance with previous reports that showed $\mathrm{B}$ and $\mathrm{T}$ cell depletion in cortical areas of secondary lymph organs such as the thymus [44] and lymph nodes [45] of PRRSV infected pigs. The immune cell depletion in lymphoid tissues has recently been associated to apoptotic cell death indirectly induced in bystander cells by PRRSV infected cells [46]. We showed a $\mathrm{T}$ cell increase in the F, mostly at $7 \mathrm{dpi}$, that could be related to the migration of $\mathrm{CD}_{4}^{+}$ helper $\mathrm{T}$ cells to the $\mathrm{F}$ area to assist the induction of $\mathrm{B}$ cell responses. During this study the macrophage population increased in the Med-LN, especially for the SU1-Bel group, which indicates that the SU1-Bel strain induces a higher inflammatory response in the lung than the other PRRSV-1 strains tested, in accordance with previous reports $[9,11]$.

Production of type I IFNs (IFN- $\alpha / \beta)$ is critical to activation of the innate immune response against viral infection, as well as regulation of the induction of the adaptive immune response $[47,48]$. We detected either no changes or lower IFN- $\alpha$ transcript levels for all PRRSV inoculated groups, most noticeably at $7 \mathrm{dpi}$, which likely plays a role in delaying the onset of an effective innate immune 
Table 4 Correlations between SU1-Bel RNA and the gene expression of TNF- $\alpha$, IFN- $a$, IFN- $\gamma$, SOCS1, IL-23p19, IL-10 and TGF- $\beta$

\begin{tabular}{|c|c|c|c|c|c|c|c|c|}
\hline & & IFN-a & IFN- $\gamma$ & IL-23 & SOCS1 & IL-10 & TGF- $\beta$ & ORF7 PRRSV \\
\hline \multirow[t]{3}{*}{ TNF-a } & $\mathrm{F}$ & -0.047 & -0.146 & $0.651^{* *}$ & -0.254 & 0.292 & 0.471 & $-0.683^{* *}$ \\
\hline & IF & -0.419 & -0.188 & 0.107 & -0.211 & -0.404 & 0.167 & -0.240 \\
\hline & $\mathrm{T}$ & -0.138 & -0.165 & 0.436 & -0.164 & -0.181 & 0.266 & $-0.549^{*}$ \\
\hline \multirow[t]{3}{*}{ IFN-a } & $\mathrm{F}$ & & -0.401 & 0.060 & -0.449 & 0.165 & $0.649^{* *}$ & -.273 \\
\hline & IF & & -0.186 & $-0.557^{*}$ & -0.258 & 0.339 & 0.193 & -0.044 \\
\hline & $\mathrm{T}$ & & -0.402 & -0.250 & $-0.629^{*}$ & 0.373 & 0.433 & -0.265 \\
\hline \multirow[t]{3}{*}{ IFN- $\nu$} & $\mathrm{F}$ & & & -0.040 & 0.432 & -0.327 & -0.229 & 0.353 \\
\hline & IF & & & 0.298 & 0.300 & -0.347 & -0.079 & 0.082 \\
\hline & $\mathrm{T}$ & & & 0.147 & 0.476 & -0.169 & -0.267 & -0.74 \\
\hline \multirow[t]{3}{*}{ IL-23 } & $\mathrm{F}$ & & & & -0.037 & 0.004 & 0.455 & -0.416 \\
\hline & IF & & & & $0.594^{*}$ & -0.318 & -0.216 & -0.124 \\
\hline & $\mathrm{T}$ & & & & $0.496^{*}$ & -0.178 & $-0.573^{*}$ & $-0.530^{*}$ \\
\hline \multirow[t]{3}{*}{ SOCS1 } & $F$ & & & & & -0.406 & -0.481 & $0.515^{*}$ \\
\hline & IF & & & & & 0.002 & -0.341 & -0.245 \\
\hline & $\mathrm{T}$ & & & & & -0.121 & -0.181 & -0.089 \\
\hline \multirow[t]{3}{*}{ IL-10 } & $\mathrm{F}$ & & & & & & 0.088 & -0.384 \\
\hline & IF & & & & & & -0.283 & -0.108 \\
\hline & $\mathrm{T}$ & & & & & & -0.246 & -0.093 \\
\hline \multirow[t]{3}{*}{ TGF- $\beta$} & $\mathrm{F}$ & & & & & & & $-0.541^{*}$ \\
\hline & IF & & & & & & & 0.052 \\
\hline & $\mathrm{T}$ & & & & & & & -0.263 \\
\hline
\end{tabular}

${ }^{*} p<0.05 ;{ }^{* *} p<0.01$. F (follicle of Med-LN), IF (interfollicular area of Med-LN) and T (Total cortical compartments of Med-LN).

response $[14,49]$. We showed that PRRSV can reduce the transcription of TNF- $\alpha$ which would also impair innate immune response and to delay the adaptive immune responses [50,51]. Interestingly, the IFN- $\alpha$ and TNF- $\alpha$ gene expression were positively correlated in LV infected pigs, both LV and SU1-Bel RNA levels were negatively correlated with the IFN- $\alpha$ gene expression, and SU1-Bel RNA levels were negatively correlated with the TNF- $\alpha$ gene expression. These results suggest that PRRSV downregulates these cytokine gene inductions at the site of infection, in agreement with previous studies [52]. These results also support the hypothesis that PRRSV-1 subtype 3 strains have developed the most efficient strategies to avoid the host immune responses among the PRRSV-1 genotype viruses. The upregulation of IFN- $\gamma$ expression at $7 \mathrm{dpi}$ is evidence of a delayed adaptive immune response in all PRRSV inoculated groups, as it has been previously described [53,54]. During this study a positive correlation between IFN- $\gamma$ gene expression and PRRSV LV and 215-06 strains suggests that PRRSV-1 subtype 1 induction of IFN- $\gamma$ expression depends directly on the presence of virus. It has been described that SOCS proteins are a pivotal regulator in both innate and adaptive immune responses [55]. Specifically SOCS1 acts as a negative regulator of IFN- $\gamma$ signaling, inhibiting the activation of STAT1 and thereby the expression of IFN- $\gamma$ mediated genes [56]. SOCS1 induction in PRRSV vaccinated/infected pigs has been described [57,58], which suggests SOCS1 expression in infected cells may be a mechanism to evade the host immune response. Nevertheless, the positively correlation of SOCS1 and IFN- $\gamma$ gene expression in the LV group could be a result of its negative feedback control system. Additional in vitro experiments may be used to elucidate the proposed SOCS1 induction by PRRSV during the initial phase of virus infection.

The IL-23 protein is an IL-12p40-IL-23p19 heterodimer that is secreted by antigen presenting cells such as macrophages and DCs. This cytokine is necessary for the differentiation and survival of Th17 cells, which can induce a pro-inflammatory reaction and the secretion of TGF- $\beta$ [59]. In this study we did not detect IL-12p40 transcripts; this could be explained by the transcription kinetics of this cytokine being earlier or later compared with the tissue sample collection points. The IL-23p19 is a limiting factor to produce a biologically active IL-23 protein, as IL-23p19 is not secreted in the absence of the IL-12p40 chain [60] and the IL-23p19 induction 
is typically lower than that of IL-12p40 [61]. In the present study, IL-23p19 was upregulated from $7 \mathrm{dpi}$, and this was statistically significant at $35 \mathrm{dpi}$ in the $\mathrm{F}$ for all PRRSV groups, which suggest that PRRSV may modulate the cytokine environment to drive the differentiation of Th17 as opposed to antiviral Th1 cells.

The IL-10 transcription levels showed considerable variation between PRRSV strains as previously described [62]. Therefore, this study supports the idea that the induction of IL-10 as a mechanism to delay the host immune response is not a common strategy among the PRRSV-1 genotype. The TGF- $\beta$ gene expression was either unaffected or downregulated in agreement with previous findings [63], and this may explain why a positive correlation between TGF- $\beta$ and other cytokines were detected in this study.

The standard techniques used to take samples for mRNA extraction cannot select different tissue structures in the way that LMC can. We therefore conclude that LMC in combination with RT-qPCR is a powerful tool to enable the differentiation of transcriptomic profiles between different Med-LN compartments of PRRSV-1 infected pigs. In this study we show several examples that demonstrate how the immunopathogenesis of PRRSV-1 infection is associated with the site of infection; for instance, PRRSV-1 SU1-Bel showed a higher tissue pathogenesis and virulence compared with PRRSV-1 subtype 1 strains. We have also provide further evidence that PRRSV-1 strains avoid the innate immune response in infected pigs through the downregulation of IFN- $\alpha$ and TNF- $\alpha$ in $F$ and IF areas of Med-LN, and inducing a T and $B$ cell depletion in the cortex of Med-LN.

\section{Competing interests}

The authors declare that they have no competing interests.

\section{Authors' contributions}

SPG, FS, FJS, JPF and TWD conceived the animal experiment and participated in the design and coordination, and helped drafting the manuscript. Experimental work performed by OGN, RSR, DR, FJP and FJS. TSS and SBM participated in the samples collection and processing for histopathology. All authors contributed to the manuscript preparation, revision and provided important intellectual input. All authors read and approved the final manuscript.

\footnotetext{
Acknowledgements

The authors would like to thank Tomasz Stadejek for provision of material for the isolation of the SU1-Bel strain and Anna Marie Rebel and Eefke Wessendorp for the provision of the Lelystadvirus. This work was supported by the PoRRSCon and NADIR Projects of the European Union Seventh Framework Programme (Grant Agreements \#245141 and \#228394 respectively), DEFRA project SE0529, EU COST action FA0902 and the British Pig Executive (BPEX). O. García-Nicolás was founded by grant BES-2010-032408 of the Ministry of Economy and Competitiveness, in part by the project AGL2009-12438 from the Government of Spain. F.J. Pallarés was supported by a grant from "Fundación Séneca", Spain. D. Risco has a "Formación de Profesorado Universitario" (FPU) grant from the Ministry of Education (AP2009-0704) from the Government of Spain.
}

\section{Author details}

${ }^{1}$ Department of Anatomy and Comparative Pathology, Faculty of Veterinary Medicine, Murcia University, "Mare Nostrum Excellence Campus - 3738", 30100 Murcia, Spain. ²Department of Bacteriology, Animal and Plant Health Agency, Addlestone, Surrey KT15 3NB, UK. ${ }^{3}$ Red de Grupos de Investigación Recursos Faunísticos, Facultad de Veterinaria, Universidad de Extremadura, 10003 Cáceres, Spain. ${ }^{4}$ Spanish National Center of Biotechnology (CSIC), C/Darwin 3, Campus de Cantoblanco, 28049 Madrid, Spain. ${ }^{5}$ Department of Virology, Animal and Plant Health Agency, Addlestone, Surrey KT15 3NB, UK. ${ }^{6}$ Department of Pathology, Animal and Plant Health Agency, Addlestone KT15 3NB, UK. 'Department of Pathology and Infectious Diseases, School of Veterinary Medicine, University of Surrey, Guildford GU2 7TE, UK.

Received: 25 July 2014 Accepted: 6 February 2015 Published online: 19 March 2015

\section{References}

1. Hopper SA, White ME, Twiddy N (1992) An outbreak of blue-eared pig disease porcine reproductive and respiratory syndrome in four pig herds in Great Britain. Vet Rec 131:140-144

2. Done SH, Paton DJ (1995) Porcine reproductive and respiratory syndrome: clinical disease, pathology and immunosuppression. Vet Rec 136:32-35

3. Rossow KD (1998) Porcine reproductive and respiratory syndrome. Vet Pathol 35:1-20

4. Zimmerman JJ, Benfield DA, Murtaugh MP, Osorio F, Stenvenson GW, Torremorell M (2006) Porcine reproductive and respiratory syndrome virus (porcine arterivirus). InStraw BE, Zimmerman JJ, D'Allaire S, Taylor DJ (eds) Ames, lowa5. Holtkamp DJ, Kliebenstein JB, Neumann EJ, Zimmerman JJ, Rotto HF, Yoder TK, Wang C, Yeske PE, Mowrer CL, Haley CA (2013) Assessment of the economic impact of porcine reproductive and respiratory syndrome virus on United States pork producers. J Swine Health Prod 21:72-84

5. Holtkamp DJ, Kliebenstein JB, Neumann EJ, Zimmerman JJ, Rotto HF, Yoder TK, Wang C, Yeske PE, Mowrer CL, Haley CA (2013) Assessment of the economic impact of porcine reproductive and respiratory syndrome virus on United States pork producers. J Swine Health Prod 21:72-84

6. Nelsen CJ, Murtaugh MP, Faaberg KS (1999) Porcine reproductive and respiratory syndrome virus comparison: divergent evolution on two continents. J Virol 73:270-280

7. Stadejek T, Oleksiewicz MB, Scherbakov AV, Timina AM, Krabbe JS, Chabros K, Potapchuk D (2008) Definition of subtypes in the European genotype of porcine reproductive and respiratory syndrome virus: nucleocapsid characteristics and geographical distribution in Europe. Arch Virol 153:1479-1488

8. Stadejek T, Stankevicius A, Murtaugh MP, Oleksiewicz MB (2013) Molecular evolution of PRRSV in Europe: current state of play. Vet Microbiol 165:21-28

9. Karniychuk UU, Geldhof M, Vanhee M, Van Doorsselaere J, Saveleva TA, Nauwynck HJ (2010) Pathogenesis and antigenic characterization of a new East European subtype 3 porcine reproductive and respiratory syndrome virus isolate. BMC Vet Res 6:30

10. Morgan SB, Graham SP, Salguero FJ, Sánchez-Cordón PJ, Mokhtar H, Rebel JM, Weesendorp E, Bodman-Smith KB, Steinbach F, Frossard JP (2013) Increased pathogenicity of European porcine reproductive and respiratory syndrome virus is associated with enhanced adaptive responses and viral clearance. Vet Microbiol 163:13-22

11. Weesendorp E, Morgan S, Stockhofe-Zurwieden N, Popma-De Graaf DJ, Graham SP, Rebel JM (2013) Comparative analysis of immune responses following experimental infection of pigs with European porcine reproductive and respiratory syndrome virus strains of differing virulence. Vet Microbiol 163:1-12

12. Lee YJ, Park CK, Nam E, Kim SH, Lee OS, du Lee S, Lee C (2009) Generation of a porcine alveolar macrophage cell line for the growth of porcine reproductive and respiratory syndrome virus. J Virol Methods 163:410-415

13. Van Gorp H, Van Breedam W, Delputte PL, Nauwynck HJ (2008) Sialoadhesin and CD163 join forces during entry of the porcine reproductive and respiratory syndrome virus. J Gen Virol 89:2943-2953

14. Albina E, Carrat C, Charley B (1998) Interferon-alpha response to swine arterivirus (PoAV), the porcine reproductive and respiratory syndrome virus. J Interferon Cytokine Res 18:485-490 
15. Meier WA, Galeota J, Osorio FA, Husmann RJ, Schnitzlein WM, Zuckermann FA (2003) Gradual development of the interferon-gamma response of swine to porcine reproductive and respiratory syndrome virus infection or vaccination. Virology 309:18-31

16. Mateu E, Diaz I (2008) The challenge of PRRS immunology. Vet J 177:345-351

17. Lopez OJ, Osorio FA (2004) Role of neutralizing antibodies in PRRSV protective immunity. Vet Immunol Immunopathol 102:155-163

18. Xiao Z, Batista L, Dee S, Halbur P, Murtaugh MP (2004) The level of virus-specific T-cell and macrophage recruitment in porcine reproductive and respiratory syndrome virus infection in pigs is independent of virus load. J Virol 78:5923-5933

19. Barranco I, Gómez-Laguna J, Rodríguez-Gómez IM, Quereda JJ, Salguero FJ, Pallarés FJ, Carrasco L (2012) Immunohistochemical expression of IL-12, IL-10, IFN- $a$ and IFN- $\gamma$ in lymphoid organs of porcine reproductive and respiratory syndrome virus-infected pigs. Vet Immunol Immunopathol 149:262-271

20. Gómez-Laguna J, Salguero FJ, Barranco I, Pallarés FJ, Rodríguez-Gómez IM, Bernabé A, Carrasco L (2010) Cytokine expression by macrophages in the lung of pigs infected with the porcine reproductive and respiratory syndrome virus. J Comp Pathol 142:51-60

21. Binns RM, Pabst, (1994) Lymphoid tissue structure and lymphocyte trafficking in the pig. Vet Immunol Immunopathol 43:79-87

22. Rezk SA, Nathwani BN, Zhao X, Weiss LM (2013) Follicular dendritic cells: origin, function, and different disease-associated patterns. Hum Pathol 44:937-950

23. Lin CM, Jeng CR, Hsiao SH, Liu JP, Chang CC, Chiou MT, Tsai YC, Chia MY, Pang VF (2011) Immunopathological characterization of porcine circovirus type 2 infection-associated follicular changes in inguinal lymph nodes using high-throughput tissue microarray. Vet Microbiol 149:72-84

24. Mendrick DL (2011) Transcriptional profiling to identify biomarkers of disease and drug response. Pharmacogenomics 12:235-249

25. Lunney JK, Fritz ER, Reecy JM, Kuhar D, Prucnal E, Molina R, Christopher-Hennings J, Zimmerman J, Rowland RR (2010) Interleukin-8, interleukin-1 beta, and interferon-gamma levels are linked to PRRS virus clearance. Viral Immunol 23:127-134

26. Miller LC, Fleming D, Arbogast A, Bayles DO, Guo B, Lager KM, Henningson JN, Schlink SN, Yang HC, Faaberg KS, Kehrli ME, Jr (2012) Analysis of the swine tracheobronchial lymphnode transcriptomic response to infection with a Chinese highly pathogenic strain of porcine reproductive and respiratory syndrome virus. BMC Vet Res 8:208

27. Wysocki M, Chen H, Steibel JP, Kuhar D, Petry D, Bates J, Johnson R, Ernst CW, Lunney JK (2012) Identifying putative candidate genes and pathways involved in immune responses to porcine reproductive and respiratory syndrome virus (PRRSV) infection. Anim Genet 43:328-332

28. García-Nicolás O, Quereda JJ, Gómez-Laguna J, Salguero FJ, Carrasco L, Ramis G, Pallarés FJ (2014) Cytokines transcript levels in lung and lymphoid organs during genotype 1 Porcine Reproductive and Respiratory Syndrome Virus (PRRSV) infection. Vet Immunol Immunopathol 160:26-40

29. Okuducu AF, Hahne JC, Von Deimling A, Wernert N (2005) Laser-assisted microdissection, techniques and applications in pathology (review). Int J Mol Med 15:763-769

30. Aranday-Cortes E, Bull NC, Villarreal-Ramos B, Gough J, Hicks D, Ortiz-Peláez A Vordermeier HM, Salguero FJ (2013) Upregulation of IL-17A, CXCL9 and CXCL10 in early-stage granulomas induced by Mycobacterium bovis in cattle. Transbound Emerg Dis 60:525-537

31. Cheng L, Zhang S, MacLennan GT, Williamson SR, Davidson DD, Wang M, Jones TD, Lopez-Beltran A, Montironi R (2013) Laser-assisted microdissection in translational research: theory, technical considerations, and future applications. Appl Immunohistochem Mol Morphol 21:31-47

32. Halbur PG, Paul PS, Frey ML, Landgraf J, Eernisse K, Meng XJ, Andrews JJ, Lum MA, Rathje JA (1996) Comparison of the antigen distribution of two US porcine reproductive and respiratory syndrome virus isolates with that of the Lelystad virus. Vet Pathol 33:159-170

33. Irving JA, Cain G, Parr A, Howard M, Angus B, Cattan AR (1996) OCT embedded sections of pathological specimens as a source of high quality RNA for reverse transcriptase/polymerase chain reaction. J Clin Pathol 49:258-259

34. Barranco I, Gómez-Laguna J, Rodríguez-Gómez IM, Salquero FJ, Pallarés FJ, Bernabé A, Carrasco L (2011) Immunohistochemical detection of extrinsic and intrinsic mediators of apoptosis in porcine paraffin-embedded tissues. Vet Immunol Immunopathol 139:210-216

35. Frossard JP, Fearnley C, Naidu B, Errington J, Westcott DG, Drew TW (2012) Porcine reproductive and respiratory syndrome virus: antigenic and molecular diversity of British isolates and implications for diagnosis. Vet Microbiol 158:308-315
36. Livak KJ, Schmittgen TD (2001) Analysis of relative gene expression data using real-time quantitative PCR and the 2(-Delta DeltaC(T)). Methods 25:402-408

37. Delgado-Ortega M, Melo S, Meurens F (2011) Expression of SOCS1-7 and CIS mRNA in porcine tissues. Vet Immunol Immunopathol 144:493-498

38. Jones M, Cordell JL, Beyers AD, Tse AG, Mason DY (1993) Detection of T and $B$ cells in many animal species using cross-reactive anti-peptide antibodies. J Immunol 150:5429-5435

39. Batista L, Pijoan C, Dee S, Olin M, Molitor T, Joo HJ, Xiao Z, Murtaugh M (2004) Virological and immunological responses to porcine reproductive and respiratory syndrome virus in a large population of gilts. Can J Vet Res 68:267-273

40. Mason DY, Cordell JL, Brown MH, Borst J, Jones M, Pulford K, Jaffe E, Ralfkiaer E, Dallenbach F, Stein H, Pileri S, Gatter KC (1995) CD79a: a novel marker for B-cell neoplasms in routinely processed tissue samples. Blood 86:1453-1459

41. Marquet F, Bonneau M, Pascale F, Urien C, Kang C, Schwartz-Cornil I, Bertho N (2011) Characterization of dendritic cells subpopulations in skin and afferent lymph in the swine model. PLoS One 6:e16320

42. Soulas C, Conerly C, Kim WK, Burdo TH, Alvarez X, Lackner AA, Williams KC (2011) Recently infiltrating MAC387(+) monocytes/macrophages a third macrophage population involved in SIV and HIV encephalitic lesion formation. Am J Pathol 178:2121-2135

43. Morgan SB, Frossard JP, Pallares FJ, Gough J, Stadejek T, Graham SP, Steinbach F, Drew TW, Salguero FJ Pathology and virus distribution in the lung and lymphoid tissues of pigs experimentally inoculated with three distinct Type 1 PRRS virus isolates of varying pathogenicity. Transbound Emerg Dis, in press

44. He Y, Wang G, Liu Y, Shi W, Han Z, Wu J, Jiang C, Wang S, Hu S, Wen H, Dong J, Liu H, Cai X (2012) Characterization of thymus atrophy in piglets infected with highly pathogenic porcine reproductive and respiratory syndrome virus. Vet Microbiol 160:455-462

45. Gómez-Laguna J, Salquero FJ, Fernández de Marco M, Barranco I, Rodríguez-Gómez IM, Quezada M, Carrasco L (2013) Type 2 Porcine Reproductive and Respiratory Syndrome Virus infection mediated apoptosis in B- and T-cell areas in lymphoid organs of experimentally infected pigs. Transbound Emerg Dis 60:273-278

46. Rodríguez-Gómez IM, Barranco I, Amarilla SP, García-Nicolás O, Salguero FJ, Carrasco L, Gómez-Laguna J (2014) Activation of extrinsic- and Daxx-mediated pathways in lymphoid tissue of PRRSV-infected pigs. Vet Microbiol 172:186-194

47. Overend C, Mitchell R, He D, Rompato G, Grubman MJ, Garmendia AE (2007) Recombinant swine beta interferon protects swine alveolar macrophages and MARC-145 cells from infection with Porcine reproductive and respiratory syndrome virus. J Gen Virol 88:925-931

48. Sadler AJ, Williams BR (2008) Interferon-inducible antiviral effectors. Nat Rev Immunol 8:559-568

49. Labarque GG, Nauwynck HJ, Van Reeth K, Pensaert MB (2000) Effect of cellular changes and onset of humoral immunity on the replication of porcine reproductive and respiratory syndrome virus in the lungs of pigs. J Gen Virol 81:1327-1334

50. Labarque G, Van Gucht S, Nauwynck H, Van Reeth K, Pensaert M (2003) Apoptosis in the lungs of pigs infected with porcine reproductive and respiratory syndrome virus and associations with the production of apoptogenic cytokines. Vet Res 34:249-260

51. Subramaniam S, Kwon B, Beura LK, Kuszynski CA, Pattnaik AK, Osorio FA (2010) Porcine reproductive and respiratory syndrome virus non-structural protein 1 suppresses tumor necrosis factor-alpha promoter activation by inhibiting NF-KB and Sp1. Virology 406:270-279

52. Murtaugh MP, Xiao Z, Zuckermann F (2002) Immunological responses of swine to porcine reproductive and respiratory syndrome virus infection. Viral Immunol 15:533-547

53. Zuckermann FA, Garcia EA, Luque ID, Christopher-Hennings J, Doster A, Brito M, Osorio F (2007) Assessment of the efficacy of commercial porcine reproductive and respiratory syndrome virus (PRRSV) vaccines based on measurement of serologic response, frequency of gamma-IFN-producing cells and virological parameters of protection upon challenge. Vet Microbiol 123:69-85

54. Jung K, Renukaradhya GJ, Alekseev KP, Fang Y, Tang Y, Saif LJ (2009) Porcine reproductive and respiratory syndrome virus modifies innate immunity and alters disease outcome in pigs subsequently infected with porcine respiratory coronavirus: implications for respiratory viral co-infections. J Gen Virol 90:2713-2723 
55. Dalpke A, Heeg K, Bartz H, Baetz A (2008) Regulation of innate immunity by suppressor of cytokine signaling (SOCS) proteins. Immunobiology 213:225-235

56. Alexander WS (2002) Suppressors of Cytokine Signalling (SOCS) in the immune system. Nat Rev Immunol 2:410-416

57. Royaee AR, Husmann RJ, Dawson HD, Calzada-Nova G, Schnitzlein WM, Zuckermann FA, Lunney JK (2004) Deciphering the involvement of innate immune factors in the development of the host response to PRRSV vaccination. Vet Immunol Immunopathol 102:199-216

58. Zhou P, Zhai S, Zhou X, Lin P, Jiang T, Hu X, Jiang Y, Wu B, Zhang Q, Xu X, Li JP, Liu B (2007) Molecular characterization of transcriptome-wide interactions between highly pathogenic porcine reproductive and respiratory syndrome virus and porcine alveolar macrophages in vivo. Int J Biol Sci 7:947-959

59. Vignali DA, Kuchroo VK (2012) IL-12 family cytokines: immunological playmakers. Nat Immunol 13:722-728

60. Cooper AM, Khader SA (2007) IL-12p40: an inherently agonistic cytokine. Trends Immunol 28:33-38

61. Shimizu J, Kaneko F, Suzuki N (2013) Skewed helper T-Cell responses to IL-12 ramily cytokines produced by antigen-presenting cells and the genetic background in Behcet's Disease. Genet Res Int 2013:363859

62. Gimeno M, Darwich L, Diaz I, de la Torre E, Pujols J, Martin M, Inumaru S, Cano E, Domingo M, Montoya M, Mateu E (2011) Cytokine profiles and phenotype regulation of antigen presenting cells by genotype-I porcine reproductive and respiratory syndrome virus isolates. Vet Res 42:9

63. Silva-Campa E, Córdoba L, Fraile L, Flores-Mendoza L, Montoya M, Hernández J (2009) European genotype of porcine reproductive and respiratory síndrome (PRRSV) infects monocyte-derived dendritic cells but not induce Treg cells. Virology 396:264-271

\section{Submit your next manuscript to BioMed Central and take full advantage of:}

- Convenient online submission

- Thorough peer review

- No space constraints or color figure charges

- Immediate publication on acceptance

- Inclusion in PubMed, CAS, Scopus and Google Scholar

- Research which is freely available for redistribution 